\title{
DAUGIAKRITERIO VERTINIMO İRANKIO IŠBANDYMAS MOKANT PADALINIŲ VALDYMO PROCEDŪRŲ
}

\author{
Gintautas Razma \\ Generolo Jono Žemaičio Lietuvos karo akademija
}

\begin{abstract}
Anotacija. Padaliniu valdymo procedūros (angl. Troop-leading Procedures) (PVP) svarbi kariūnu ir kursu dalyviu ugdymo disciplina. Mokant padaliniu valdymo procedūru, siekiama išmokyti kariūna taikyti sistemini planavimo algoritma sprendžiant tipines ir kartotines karinio veikimo problemas. Tai - viena svarbiausiu būsimojo karininko vadybinio raštingumo sudedamujų dalių. Nors PVP ir svarbus mokomasis dalykas, iki šiol stokojama patikimu karinio mokymo prieigu. Straipsnyje nagrinejjama, ar daugiakriterio vertinimo metodas (angl. Multi-criteria evaluation) gali büti taikomas mokant padaliniu valdymo procedūru ir vertinant šio dalyko mokymo procesą. Atliekant veiklos tyrima praktiškai buvo išbandytas daugiakriterio vertinimo ịrankis. Tyrimas atskleide, kad daugiakriterio vertinimo metodas gali būti sèkmingai taikomas mokant padaliniu valdymo procedūru ir šio mokymo proceso rezultatams juvertinti. Nustatyta, kad ši naujove sudaro salygas gerinti pasiekimu vertinimo rezultatus, formuoti teigiamas nuostatas ir požiūri i mokymą(si), be to, padeda mokytojui efektyviau veikti mokymo metu.
\end{abstract}

Reikšminiai žodžiai: karinis ugdymas, padalinių valdymo procedūros, daugiakriteris vertinimas, mokymo proceso vertinimas.

\section{Ivadas}

Besikeičiantis požiūris ị mokymą(si) keičia ir požiūrị i jo rezultatų vertinimą bei paskirti ugdymo procese. Nors vertinimo tikslai iš esmès nepasikeitè, tačiau pastebima atsakomybès už išmokimą perleidimo besimokančiajam tendencija, taip pat kad tradicinès mokymosi pasiekimų vertinimo (angl. Assessment of learning) praktikos keičiamos naujomis mokymui(si) įvertinti (angl. Assessment for learning) skirtomis praktikomis. Tai akivaizdi atsakomybės už išmokimą persiskirstymo tarp besimokančiojo, mokytojo ir ugdymo ịstaigos apraiška (Bybee, 2003; Gudžinskie-

\footnotetext{
* Generolo Jono Žemaičio Lietuvos karo akademijos Karybos studijų grupės Taktikos sekcijos vyriausiasis instruktorius ir politikos mokslų doktorantas,

Šilo g. 5A, 10322 Vilnius,

el.p.gintautas.razma@lka.lt
} 
nè, 2011). Galima teigti, kad tai susiję su formuojamojo vertinimo funkcijos svarbos iškilimu šiuolaikiniame ugdymo procese (Hawe \& Dixon, 2017).

Praktikos, skirtos mokymuisi ịvertinti, gali būti ịgalintos taikant ịvairius alternatyvius metodus. Pavyzdžiui, Drisko (2014) siūlo taikyti standartizuotų testų, sukurtos pridètinès vertès arba projektinio darbo vertinimo metodų alternatyvas. Kiti autoriai išskiria studento aplanko (angl. Portfolio) (Fokienė \& Sajienė, 2009), i besimokantiji orientuoto vertinimo ciklų (Cathcart et al., 2014) metodų alternatyvas. Iš naujų vertinimo metodų galima išskirti ir daugiakriterio vertinimo (angl. Multi-criteria evaluation) metodą, kuris ịprastai yra naudojamas sprendžiant technines problemas. Vis dèlto Ginevičius \& Podvezko (2008) teigia, kad daugiakriterio vertinimo metodas gali būti sèkmingai taikomas ir socialinèms problemoms spręsti. Atsižvelgiant ị tai, galima daryti prielaidą, kad daugiakriterio vertinimo metodas taip pat gali būti sėkmingai taikomas ir sprendžiant ugdymo problemas. Tai gali būti perspektyvus požiūris kuriant pažangias karinio ugdymo inovacijas.

Ugdymo inovacijų poreikis, rengiant karius Lietuvos kariuomenei, neabejotinas. Pavyzdžiui, naujojoje Generolo Jono Žemaičio Lietuvos karo akademijos (toliau - LKA) 2018-2024 m. strategijoje (2019) iškeltas patyrimu grịsto ugdymo interesas. Kitaip tariant, yra poreikis sudaryti sąlygas besimokantiesiems individualų žinojimą konstruoti savitai, atsižvelgiant ị tai, koks yra kiekvienas žmogus (Valuckienė, 2009). Nors LKA ugdymo interesas yra aiškus, tačiau stokojama patikimų praktinių sprendimų, kad šie interesai būtų kokybiškai ịgyvendinti. Tai atskleidžia faktas, kad šiuo metu yra net penkios skirtingos kursantų (kariūnų, aspirantų, klausytojų, rezervo karių ir specialistų) karinio ugdymo programos, kuriomis remiantis iš esmès siekiama parengti jaunesniji karininką - leitenantą. Akivaizdu, kad stokojama sutarimo, kokių žinių turi būti ịgiję kursantai, baigusieji LKA ar jos organizuojamus kursus, kokiomis teorinėmis prieigomis ir strategijomis remiantis galètu būti sẻkmingai rengiami šie kariai. Kaip pažymi Drisko (2014, p. 419), didžioji problema susijusi su instituciniu negebejjimu pateikti tikslų rengiamo specialisto profesinio paveikslo vaizdini - tam tikrą ugdomų profesinio raštingumo (angl. literacy), kompetenciju (angl. competency) ir charakterio savybiu (angl. character qualities) rinkinį. Tokio poreikio atspirties tašku galima laikyti XXI amžiaus iggūdžiu (angl. 21st-Century Skills) modelio pavyzdi (World Economic Forum, 2015, p. 3). Profesinio paveikslo vaizdinio stoka riboja galimybes kokybiškai mokyti, mokytis ir vertinti.

Ši mokymo, mokymosi ir vertinimo procesų dermès problema kyla ir mokant karius padalinių valdymo procedūrų (toliau - PVP). Dèl to kyla poreikis kurti ir taikyti naujoves ir, jas taikant, siekti kurti kokybiškesnes žinias. Atsižvelgiant ị tai ir yra keliamas šis tyrimo klausimas - ar daugiakriterio vertinimo metodas gali būti efektyviai taikomas mokant PVP?

Tyrimo objektas - daugiakriterio vertinimo įrankio tinkamumas mokymui.

Tyrimo uždavinys - išbandyti daugiakriterio vertinimo įrankị LKA mokant II kurso kariūnus PVP. 


\section{Tyrimo siekiniai:}

1. Ivertinti daugiakriterio vertinimo ịrankio įtaką mokymo(si) pasiekimams (rezultatams).

2. Ivvertinti daugiakriterio vertinimo ịrankio įtaką kariūnų nuostatoms ir požiūriui ị mokymą(si).

3. Reflektuoti apie daugiakriterinio vertinimo įrankio tolesnio taikymo galimybes mokymo(si) procese.

Tyrimo tikslas - išplèsti žinias apie daugiakriterio vertinimo metodo taikymo galimybes karinio ugdymo srityje.

\section{Teorinis tyrimo kontekstas}

Scott \& Webber (2008) teigia, kad mes gyvename amžiuje, kuriame atskaitomybe, taip pat ir apskaita, yra labai svarbios šiuolaikinio progreso sampratos dalys. Objektyvi ir efektyvi apskaita galima tik tada, kai svarbūs objektai yra aiškiai identifikuoti ir konceptualizuoti. Apskaitai svarbūs objektai yra vertinimo (angl. Evaluation) ir įvertinimo (angl. Assessment) sąvokos. Tačiau vertinimo ir ịvertinimo sąvokų reikšmès neretai yra painiojamos, netiksliai įvardijamos. Vertinimas (angl. Evaluation) padeda suformuluoti reikalingas išvadas sprendimams priimti, o įvertinimas (angl. Assessment) - surinkti duomenis ir informaciją apie konkrečios veiklos ar jos dalies faktinę būseną. Vertinimas yra nuolatinis procesas, ịvertinimas momentinis kiekybinès prigimties veiksmas. Ivertinimas yra reikalingų duomenu ar informacijos užfiksavimo veiksmas. Dèl to apibendrinamasis procesas - vertinimas - negali būti sėkmingas be efektyvaus įvertinimo. Kadangi daugiakriteris vertinimas visada turi būti grindžiamas aiškia hierarchine struktūra (Katinienė, 2018), ši problema taikant daugiakriterius vertinimo metodus nèra labai aktuali. Galima teigti, kad praktiškai daugiakriteriai vertinimo metodai yra palankūs rengiant praktinius įvertinimo įrankius.

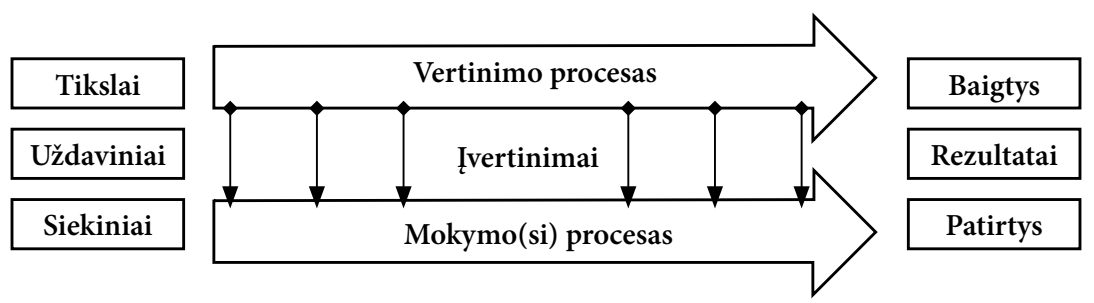

1 pav. Vertinimo ir mokymo(si) procesų sąsajų schema (sudaryta autoriaus)

Mokymas (angl. teaching) ir mokymasis (angl. learning) - sudètingas dualistinis mokytojo, besimokančiojo ir juos supančios aplinkos socialinès interakcijos procesas, todèl, siekiant kryptingo mokymo(si), tipiškai kiekvieno etapo pradžioje yra keliami konkretūs mokymo(si) tikslai, uždaviniai ir (ar) siekiniai. Natūralu, kad mokymo(si) etapo pabaigoje tikimasi ir reikalaujama konkrečių išmokimo baigčių, 
rezultatų ir teigiamų patirčių. Tačiau čia kyla esminis klausimas: kaip tai bus igyvendinta, o dar svarbiau - kaip tai bus suvaldyta? Ir kaip bus patikrinta siekiniu bei lūkesčiu atitiktis gautiems rezultatams ir patirtims? Taigi, organizuojant vertinimo procesą siekiama užtikrinti, kad suplanuoti tikslai, uždaviniai ir siekiniai būtų kryptingai igyvendinti, o realios baigtys, rezultatai ir patirtys atitiktų numatytus lūkesčius (žr. 1 pav.). Tai suponuoja išvadą, kad tokiai transformacijai turi būti užtikrinta kokybiška mokymo(si) ir vertinimo procesų dermé, laiduojama per tikslingus ivertinimus.

Tai leidžia paaiškinti, kodèl vertinimas yra būtina ir karinès edukacijos funkcija, sudaranti sąlygas priimti svarbius ir reikalingus sprendimus (BI-SC DIR 075-073, 2015; Ramoniene et al., 2012). Tai taip pat yra ,sistemingas duomeny rinkimo, ìvertinimu analizès, projektavimo, kūrimo ir igyvendinimo procesas, kuris atliekamas siekiant užtikrinti, kad mokymas atitiktu numatytas mokymo(si) baigtis (angl. outcomes) " (BI-SC DIR 75-2, 2013, p. C-5). Pats vertinimo procesas nèra atsiejamas nuo efektyvaus reikalingų duomenų, informacijos, žinių tvarkymo. Tai tapo ypač aktualu ịvairialypių ir didelių duomenų srautų (angl. Big data) tvarkymo amžiuje. Svarbu pažymèti, kad vertinimas apima ne tik besimokančiujų mokymo(si) pažangos apskaitą, bet ir ,tam tikro ju intelektinio pajegumo pokyčius ir (žinias - aut.) mokymo metodu arba programu efektyvuma " (Gatautis et al., 2008). Dèl to šiuolaikinèms ir pažangos siekiančioms organizacijoms reikia rasti efektyvesnių vertinimo metodų, kurie sudarytų sąlygas autonomiškai tvarkyti didelius reikalingų duomenų srautus. Žvelgiant ị karinio ugdymo srities atveji galima teigti, kad daugiakriterio vertinimo metodo taikymas galètų leisti nustatyti ne tik konkretaus besimokančiojo žinių lygị ir spragas, bet ir konkretaus mokymo, net institucinio, privalumus ir trūkumus.

Daugiakriteris vertinimo metodas yra kiekybinis. Dèl to iš pirmo žvilgsnio gali atrodyti, kad šio metodo taikymo ugdymo srityje galimybės yra ribotos. Pasak Ginevičiaus ir Podvezko (2008), nors daugiakriteris vertinimo metodas tipiškai yra naudojamas techninèms problemoms spręsti, tačiau taip pat gali būti taikomas ir atliekant socialinių reiškinių kiekybinį vertinimą. Daugiakriteris vertinimo metodas remiasi redukcionizmo filosofija, t. y. samprata, kad bet kurị, net ir labai sudètingą, reiškini galima suskaidyti ị labai smulkias dalis, o suskaidytas dalis hierarchiškai struktūruoti ị visumą ir kiekybiškai įvertinti nustatant konkrečias jų vertes. Kaip vieną daugiakriterio vertinimo metodo privalumų Ginevičius \& Podvezko (2008) ìvardija ir tai, kad ne tik gaunamas vienas apibendrinamasis įvertinimas - pavyzdžiui, galutinis pažymys, bet ir nustatoma tam tikrų dalių rinkinių ar konkretaus kriterijaus įvertinimo verte. Tai įmanoma padaryti, nes visi rodikliai yra susieti hierarchiniais priežastiniais ryšiais, normalizuoti ir palyginami tarpusavyje. Jeigu konkretaus kriterijaus verte pakinta, atitinkamai kinta ir viso vertinamo reiškinio vertè. „Kitaip tariant, daugiakriterinio vertinimo metodai taikomi kaip sprendimu priemimo palaikymo sistema "(Ginevičius \& Podvezko, 2008, p. 82).

Daugiakriteris vertinimo metodas pasižymi tuo, kad galima kompleksiškai 
įvertinti sudètingus reiškinius ar procesus. Priešingai nei tradiciniai vertinimo metodai, daugiakriteris vertinimo metodas gali užtikrinti, kad procesai, projektai ar reiškiniai bet kurio tuo metu atliekančio vertinimą vertintojo būtų vertinami vadovaujantis tais pačiais vertinimo kriterijais ir, tikètina, būtų gaunami gana objektyvūs vertinimo rezultatai. Pavyzdžiui, mokant PVP, daugiakriteris vertinimo metodas, nepriklausomai nuo planuojamos karinès operacijos tipo, operacinio įsakymo formos ar jo detalumo, aiškiai standartizuoja ir struktūruoja PVP mokymo proceso vertinimo logiką, nesvarbu, kuris vertintojas atlieka vertinimą. Tai leidžia maksimaliai sumažinti vertintojų galimą subjektyvumo ịtaką vertinimo procesui. Dèl to daugiakriteris vertinimo metodas pagrịstai gali būti laikomas patikimu ir objektyviu (Katinienė, 2018).

Žinoma, vis dèlto būtina įvertinti ir tą aplinkybę, kad ugdymas nèra mechaninis procesas. Dėl šios priežasties ugdymo srityje pasireiškia daugiakriterio vertinimo metodo pritaikomumo ribotumas. Ugdymo proceso esminis objektas yra žmogus, o ne mašina. Dẻl to racionalus ir vienareikšmis daugiakriteris vertinimo metodas neabejotinai ịspraudžia žmogiškajị veiksnị ị labai konkrečius rėmus. Tai prieštarauja ir šiuo metu švietimo sistemoje dominuojančiai humanizmo ideologijai. Vis dèlto, atsižvelgiant ị XXI amžiaus iggūdžiu (angl. 21st-Century Skills) modelio pavyzdị (World Economic Forum, 2015, p. 3), galima teigti, kad daugiakriterio vertinimo metodas, tikètina, gali būti sẻkmingai pritaikytas ugdant profesinị raštingumą (angl. literacy).

PVP yra amerikietiškosios karinès minties produktas, jų sukurta technologija. PVP apibrěžia vadybinio raštingumo žinias kaip tam tikrą karinio valdymo, o dar tiksliau - planavimo algoritmą. Česūno (2015) vadovèlis ịtvirtino nuostatą, kad PVP yra Lietuvos krašto apsaugos sistemos institucinis pasirinkimas rengiant karius. PVP - techninès žinios, sudarančios nuoseklią aštuonių mokymosi žingsnių seką (ADP 5-0, 2019, p. 2-18). Tai - tipinis planavimo algoritmas, kuriame tiksliai įvardytas kiekvienas žingsnis: 1. „Gauk uždavini.““ 2. „Ispèk valdinius.“ 3. „Sudaryk pirmini planą.“ 4. „Inicijuok judèjimą.“ 5. „Išžvalgyk.“ 6. „Užbaik planą.“ 7. „Išleisk kovinị ịsakymą.“ 8. „Prižiūrèk ir įvertink.“ PVP skirtos tipinėms, kartotinèms karinio veikimo problemoms spręsti. Tokia PVP žinių prigimtis sudaro sąlygas konstruoti daugiakriterio vertinimo metodu grịstus PVP mokymo(si) įrankius. Autorius kelia idejją, kad tokie daugiakriterio vertinimo įrankiai, skirtingai nuo tradicinių vertinimo įrankių, galètų būti naudojami universaliai ugdymo procese atliekant tiek formuojamaji, tiek diagnostini, tiek apibendrinamaji vertinimą. Pirmiausia daugiakriterio vertinimo įrankiai, parengti konkrečiam mokymo(si) etapui, galètu būti naudojami pradinių žinių konstravimo interesui skatinti per formuojamajị vertinimą. Vèliau, atliekant diagnostinị vertinimą, naudojant tuos pačius daugiakriterio vertinimo įrankius, galètų būti nustatomos individualios ir kolektyvinès besimokančiųjų žinių spragos. Galiausiai, atliekant apibendrinamajį vertinimą, naudojant tuos pačius daugiakriterio vertinimo įrankius, galètų būti nustatyti individualūs mokymosi (išmokimo) rezultatai. Tokia formuojamojo, diagnostinio ir apibendrinamojo vertinimų sintezè, tikètina, sudarytų palankias sąlygas besimokantiesiems geriau 
ịsisavinti dèstomojo dalyko medžiagą, pasiekti aukštesnius mokymosi rezultatus ir formuotų teigiamas nuostatas, požiūrị ị mokymą(si). Taip pat labai tikètina, kad daugiakriterio vertinimo įrankių naudojimas palengvintų mokytojų darbą ir leistų pagerinti ugdymo proceso kokybę instituciniu lygmeniu.

Atlikus mokslo tiriamujų darbų, kuriuose siekiama paaiškinti, kaip daugiakriterio vertinimo metodai galètų būti taikomi karinio ugdymo srityje, paiešką, tenka pripažinti, kad tokių darbų autoriui nei užsienio, nei lietuvių kalba nepavyko rasti. Kitų sričių tiriamujų darbų gausa patvirtina faktą, kad daugiakriterio vertinimo metodas yra skirtas techninėms problemoms spręsti. Vis dèlto Ginevičiaus \& Podvezko (2008) įžvalga, kad daugiakriterio vertinimo metodas gali būti pritaikytas ir socialinių reiškinių tyrimui, skatina įvertinti šias galimybes ir perspektyvas karinio ugdymo srityje. Nepaisant karinio ugdymo srities tyrimų deficito, galima rasti ir artimų tyrimų. Daugiausia tyrimo objektui artimų tyrimų yra atlikę Kinijos mokslininkai (Chang \& Wang, 2016; Ketkar \& Vaidya, 2014; Li et al., 2019; Lin et al., 2014; Shee \& Wang, 2008; Zare et al., 2016). Kadangi pastebima tokių tyrimų stoka, galima pagrịstai teigti, kad šis tyrimas tenkina naujumo kriterijų ir išplečia daugiakriteriškumu grindžiamų ugdymo strategijų teorinių ir praktinių sprendinių aiškinimą. Taip pat šio tyrimo rezultatai gali sudaryti palankias prielaidas šiuos sprendinius plačiau taikyti aukštojo mokslo, profesinio rengimo ir bendrojo ugdymo institucijose.

\section{Tyrimo metodologija}

Siekiant tinkamai išbandyti ir ịvertinti, ar daugiakriteris vertinimo metodas gali būti taikomas mokant PVP ir vertinant jų mokymo rezultatus, būtina disponuoti patikima metodologija. Metodologija - tai kompleksinè metodų, skirtų tiriamo reiškinio savybèms atskleisti, logika. Kadangi atliekant ši tyrimą buvo siekiama rasti ivvardytos problemos sprendimą, buvo pasirinktas ir adaptuotas Sarraf et al. (2013, p. 865) pateiktas daugiakriterio sprendimo prièmimo (MCDM, angl. multiple criteria decision-making) metodologinis pavyzdys. Tyrimą sudare keturi žingsniai:

1. Siekinių, skirtų problemai spręsti, identifikavimas.

2. Daugiakriterio vertinimo įrankio, skirto mokomojo dalyko PVP mokymui, sudarymas.

3. Sudaryto daugiakriterio vertinimo įrankio, skirto mokomojo dalyko PVP mokymui, išbandymas.

4. Daugiakriterio vertinimo įrankio tinkamumo mokomojo dalyko PVP mokymui įvertinimas.

1-as žingsnis - siekinių identifikavimas. Atsižvelgiant ị iškeltą tyrimo klausimą ir uždavinị, šio straipsnio ịvadinèje dalyje buvo suformuluoti trys aktualūs siekiniai (žr. ịvade). Jie leido sudaryti, išbandyti ir patikimai ịvertinti daugiakriterio vertinimo įrankio tinkamumą PVP mokyti.

2-as žingsnis - daugiakriterio vertinimo ịrankio sudarymas. Šiame etape buvo sukurta daugiakriterio vertinimo įrankio struktūra, nustatyti vertinimo krite- 
rijai, vertinimo kriterijų reikšmingumas, parinkta ir normalizuota vertinimo skale, identifikuoti išbandyti skirti vertinimo būdai ir galiausiai parengti detalieji, kiekvienam mokymo(si) etapui skirti, vertinimo lapai.

Kuriant vertinimo įrankio struktūrą buvo atlikta PVP aiškinančių pirminių (FM 3-21.10, 2006, Chapter 2; FM 3-21.8, 2007, Chapter 5, Section III) ir antriniu (Česūnas, 2015) šaltinių turinio analizè. Autorius deklaruoja, kad turinio analizei nebuvo naudoti atnaujinti pirminių šaltinių leidimai (ATP 3-21.10, 2018; ATP 3-21.8, 2016), nes, kai buvo atliekamas tyrimas, autorius neturejo galimybès su minètais šaltiniais susipažinti. İ tai ateityje reikètų atsižvelgti. Nepaisant ribotų galimybių, atlikus pirminių ir antrinių šaltinių turinio analizę buvo sudaryti nestruktūrizuoti vertinimo kriterijų rinkiniai. Nors vertinimo kriterijai nusako, ką besimokantysis turi pasiekti, tačiau taip pat labai svarbu apibrèžti, kaip tie pasiekimai yra vienas su kitu susiję. Remiantis Katinienès (2018) ir Simanavičienès (2011) disertacijomis, sudarant PVP daugiakriterio vertinimo kriterijų struktūrą buvo pasitelktas analitinis hierarchijos procesas (toliau - AHP, angl. Analytic Hierarchy Process). AHP esmè - panaudojant tyrèjo analitinę kompetenciją, smulkinti sudètingo reiškinio visumą i smulkesnius elementus tol, kol galiausiai kiekvienas elementas galès būti vienareikšmiškai pažintas. Tokia susmulkinta visuma per aiškiai susietą hierarchinę elementų struktūrą leidžia ịvertinti reiškinio ar jo dalies būseną.

Kadangi daugiakriteris vertinimo metodas yra išskirtinai kiekybinis, sudarius vertinimo įrankio hierarchinę struktūrą, būtina nustatyti kiekvieno vertinimo kriterijaus reikšmingumo vertę. Taikant AHP metodą vertinimo kriterijų reikšmingumo vertès apskaičiuojamos naudojant visų vertinimo kriterijų porinio lyginimo matricą (Katinienè, 2018, p. 170). Tačiau tokią vertinimo kriterijų reikšmingumo apskaičiavimo metodiką gali būti sudètinga naudoti, kai vertinimo kriterijų skaičius pakopoje yra gana didelis. Pasak Katinienès (2018), AHP ir paprastojo suminio vertinimo metodai (toliau - SAW, angl. Simple Additive Weighing) puikiai vienas kitą papildo, kai taikomi kartu. Svarbus SAW metodo pranašumas tai, kad visos vertinimo kriterijų vertès yra apibendrinamos viena verte. Vertinimo kriterijų reikšmingumui nustatyti atliekamas ekspertinis vertinimas, pasitelkiant vertinimo kriterijų rangavimą. SAW ypač patikimas metodas, taikomas normalizuojant vertinimo kriterijų reikšmingumo vertes, nes nėra jautrus nei alternatyvų skaičiaus, nei rodiklių reikšmingumo kitimui (Simanavičienė \& Ustinovičius, 2011). Kiekvienoje pakopoje kriterijų reikšmingumas gali būti ịvertintas nuo 0 iki 1 , o jų suma turi būti lygi vienetui. Reikšmingumo suma apskaičiuojama pagal formulę:

$$
\sum_{\mathrm{i}=1}^{n} \omega_{\mathrm{i}}=1,
$$

čia: $\boldsymbol{\omega}_{\boldsymbol{i}}-i$-ojo kriterijaus reikšmingumas; $\boldsymbol{i}$ - atitinkamos pakopos kriterijų indeksai; $\boldsymbol{n}$ - atitinkamos pakopos kriterijų skaičius (Ginevičius \& Podvezko, 2008). 
O apibendrinamoji vertė taikant SAW metodą apskaičiuojama pagal formulę:

$$
S_{j}=\sum_{\mathrm{i}=1}^{n} \omega_{\mathrm{i}} r_{i j},
$$

čia: $S_{j}-j$-osios alternatyvos integruotojo kriterijaus verté; $\boldsymbol{\omega}_{\boldsymbol{i}}-i$-ojo kriterijaus reikšmingumas; $\boldsymbol{r}_{i j}-i$-ojo kriterijaus normalizuota reikšmé $j$-ajai alternatyvai; $\boldsymbol{j}$ - alternatyvų indeksai; $\boldsymbol{i}$ - kriterijų indeksai; $\boldsymbol{n}$ - kriterijų skaičius (Ginevičius \& Podvezko, 2008).

PVP vertinimo kriterijų reikšmingumo vertès buvo nustatytos taikant tyrèjo turimas ekspertines vadybinio raštingumo žinias ir profesinę kompetenciją ir naudojant 1 formulę. Vertinimo kriterijų reikšmingumo nustatymo procese buvo atsižvelgta ir ị iki šiol buvusią tradicinę PVP vertinimo praktiką. SAW metodu nustatytos PVP daugiakriterio vertinimo sistemos pirmosios pakopos vertinimo kriterijų reikšmingumo vertès ir jų galimos alternatyvos pateiktos 1 lenteleje. Svarbu akcentuoti, kad, atsižvelgiant ị konkretaus modulio mokymo(si) poreikius, galima laisvai eliminuoti tam mokymui neaktualius vertinimo kriterijus. Dẻl to nèra išbalansuojama pati vertinimo sistema, nes pagal kriterijaus svarbos vertę iš karto yra normalizuojamos $\omega$ vertès.

1 lentelè. PVP pirmos pakopos vertinimo kriterijų reikšmingumo galimos alternatyvos (sudaryta autoriaus)

\begin{tabular}{ccccc}
\hline Kriterijus & Svarba & \multicolumn{3}{c}{ Galimos $\boldsymbol{\omega}$ alternatyvos } \\
\hline Pirminis įvertinimas & 2 & 0,10 & 0,125 & - \\
\hline Ispejjamojo įsakymo išleidimas & 1 & 0,05 & - & - \\
\hline Pirminio kovinio plano sudarymas & 10 & 0,50 & 0,625 & $0,(6)$ \\
\hline Judèjimo plano sudarymas & 1 & 0,05 & - & $0,0(6)$ \\
\hline Žvalgymo plano sudarymas & 1 & 0,05 & - & - \\
\hline Kovinio plano išbaigimas & 2 & $\mathbf{0 , 1 0}$ & 0,125 & $0,1(3)$ \\
\hline Kovinio ịsakymo išleidimas & 2 & 0,10 & 0,125 & - \\
\hline Priežiūra ir ịvertinimas & 1 & 0,05 & - & $0,0(6)$ \\
\hline Suma: & $\mathbf{2 0}$ & $\mathbf{1 , 0 0}$ & $\mathbf{1 , 0 0}$ & $\mathbf{1 , 0 0}$ \\
\hline
\end{tabular}

Remiantis 2 formule kyla poreikis visam PVP daugiakriterio vertinimo ịrankiui parinkti vieną vertinimo skalę ir nustatyti joje normalizuotas pasirinkimo alternatyvas. Svarbu pažymèti, kad mokant PVP svarbus kaupimo principas, dèl to tikslinga naudoti nominalinę (identifikavimo) vertinimo skalę (Dikčius, 2011, p. 53). Nors tinkamų skalių parinkimas ir priderinimas prie sukurtos vertinimo sistemos yra svarbus veiksnys, tačiau visais atvejais tai susiję su alternatyvomis ir jų pasirinkimu. Kuo daugiau pasirinkimo alternatyvų, tuo sunkiau objektyviai parinkti tinkamą alternatyvą. Atsižvelgus ị poreikị mažinti subjektyvumo faktoriaus daromą 
įtaką ugdymo procesui, buvo nuspręsta naudoti šią nominalinę skalę:

- „Taip“ - suteikia dichotominiam klausimui skaitinę vertę „1“.

- „Ne“ - suteikia dichotominiam klausimui skaitinę vertę „,0“.

- „Iš dalies“ - suteikia dichotominiam klausimui skaitinę vertę „0,5“.

- „Nevertinama“ - suteikia dichotominiam klausimui skaitinę vertę „999“.

Atsižvelgus ị kiekybinę daugiakriterio vertinimo metodo prigimtị, sukurtą daugiakriterio vertinimo įrankị ir parinktą nominalinę vertinimo skalę, buvo nuspręsta reikalingus duomenis rinkti naudojant daugiakriterius pasiekimų tikrinimo sąrašus (angl. checklist). Daugiakriteriai pasiekimų tikrinimo sąrašai, kitaip suprantami kaip mokymo(si) etapu vertinimo įrankiai, yra paremti vertinimo pagal kontrolinį sąrašą koncepcija (Ramonienè et al., 2012, pp. 222-223). Tokie sąrašai per dichotominių klausimų rinkinius leido surinkti tyrimui reikalingus duomenis.

3-ias žingsnis - daugiakriterio vertinimo įrankio išbandymas. Ugdymo procesas - nevienareikšmis ir komplikuotas reiškinys, kuriam būdinga mokymo(si) konteksto daroma įtaka. Dèl to, diegiant inovacijas, būtina naudoti lankstų tyrimo metodą. Atsižvelgus i lankstumo poreikị buvo nuspręsta taikyti veiklos tyrimo (angl. action research) alternatyvą (Manfra, 2019; Tripp, 2005; Tsai, 2014). Veiklos tyrimas yra lankstus metodas, nes, skirtingai nuo kitų metodų, tyrëjas pats dalyvauja procese ir daro ịtaką jo eigai. Šio metodo privalumas yra tai, kad tyrèjas gali reaguoti ị kylančius iššūkius ir prie jų prisitaikyti bei rasti netikètų sprendimų, kurių iš anksto nenumate ar negalëjo numatyti. Čia svarbi ne tik tyrimo problemos analizé, bet ir paties tiriamojo reiškinio - mokymo(si) praktikos - pokytis (Manfra, 2019, p. 164). Kitaip tariant, be mokymo(si) tikslų tyrèjas siekia ir mokslo pažinimo tikslų per realias praktines patirtis. Pasak Tripp (2005, p. 2), veiklos tyrimas atliekamas remiantis ciklu planuok-veik-apibüdink-vertink (angl. plan-actdescribe-evaluate). Planuok praktikos gerinimą, veik - igyvendink planuotą praktikos gerinimą, stebèk ir apibūdink veiksmų sukeltus efektus, vertink veikimo baigtis (angl. outcomes). Tai palankus tyrimo metodas išbandant daugiakriterio vertinimo įrankị mokant PVP.

Veiklos tyrime dalyvavo 37 LKA II kurso kariūnai. Specializuota tyrimo dalyvių ar tyrimo grupès atranka nebuvo daroma, o II kurso kariūnai tyrime dalyvavo kaip mokymo proceso dalyviai. Tyrimo dalyvių pasiskirstymas pagal lyti - 3 moterys ir 34 vyrai. Tyrimo dalyvių amžius - nuo 20 iki 26 metų. Tyrimas atliktas LKA, prisitaikius prie ugdymo ciklo ritmo. Veiklos tyrimas vyko nuo $2018 \mathrm{~m}$. spalio 4 d. iki 2018 m. lapkričio 29 d. Tyrejas dalyvavo kariūnus mokydamas PVP kaip dèstytojas. Daugiakriteris vertinimo ịrankis atliekant veiklos tyrimą buvo naudotas septyniuose šio mokomojo dalyko mokymo etapuose: T1 - „Pirminis įvertinimas“, T2 - „Uždavinio veiksnio ir turimo laiko veiksnio įvertinimas“, T3 - „Vietovès ir oro sąlygų veiksnio ịvertinimas“, T4 - „Priešiškų pajègų veiksnio įvertinimas“, T5 - „Draugiškų pajėgų veiksnio įvertinimas“, T6 - „Būrio veiksmų eigos varianto sudarymas“ ir T7 - „Kovinio plano išbaigimas“.

Veiklos tyrimas buvo atliktas laikantis mokslinio objektyvumo (tikslus nau- 
dojamų tyrimo metodų aprašymas ir taikymas, faktinių duomenų fiksavimas), savanoriškumo (tyrimo duomenys renkami nevaržant kariūnų apsisprendimo laisvès) ir konfidencialumo (užtikrintas duomenų šaltinio slaptumo išlaikymas), taip pat kitu akademinès etikos principų.

\section{4-as žingsnis - daugiakriterio vertinimo ïrankio tinkamumo ivertinimas.}

Veiklos tyrimo duomenų fiksavimui ir gautų duomenų vertinimui tipiškai naudojami kokybiniai metodai. Dèl to buvo nuspręsta naudoti mokytojo dienoraščio, grį̌ztamojo atsiliepimo (angl. feedback) ir mokinių darbų turinio analizès metodus.

Mokytojo dienoraščio metodas skirtas momentiniams faktiniams duomenims ir patirtims fiksuoti. Taip surinkti duomenys yra vertingi, nes būna užfiksuoti raštu iš karto, kai tik atsiranda. Dẻl šios priežasties surinkti duomenys labiau atspindi tikrovę, tad yra mažesnè tikimybė, kad faktiniai duomenys bus iškraipyti. Mokytojo dienoraštis naudojamas kaip duomenų ir patirčių, kurios vèliau bus mokytojo reflektuotos, rinkimo įrankis.

Žinios apie kariūnų požiūrị ị PVP mokymo(si) procesą buvo renkamos naudojant grižtamojo atsiliepimo metodą, kuris yra nesudètingas ir veiksmingas kaupiant tyrimui reikalingus duomenis. Kariūnai nebuvo verčiami pateikti grįžtamajji atsiliepimą - dèl to jie galèjo savarankiškai apsispręsti. Grịžtamieji atsiliepimai buvo anonimiški, o gauti duomenys panaudoti pokyčiams matuoti ir patirtims atskleisti.

Nors veiklos tyrime tipiškai yra naudojami kokybiniai metodai, tačiau autorius ị veiklos tyrimą ịtraukè ir kiekybinị metodą - daugiakriterị vertinimo ịrankị. Toks sprendimas leido objektyviai fiksuoti kariūnų mokymosi pokyčius ir atlikti statistinę analizę - panaudoti aprašomosios statistikos ir lyginimo metodus. Statistinei analizei reikalingi duomenys buvo renkami naudojant „Google Forms“ apklausų sistemą, o apdorojami - naudojant elektroninę „MS Excel“" skaičiuoklę.

\section{Tyrimo rezultatai (diskusija)}

Tyrimo eigos apibūdinimas. PVP mokyti buvo pradèta nuo T1 mokymo(si) etapo. Kariūnai gavo praejusių metų 4 kurso kvalifikacinio egzamino įsakymą „Žaibas“. Pirmiausia teoriškai buvo išdèstyta T1 etapo teorinè medžiaga, paaiškinta mokymosi įrankio (PVP bloknoto v3 versija) pildymo tipinè seka. Vèliau kariūnai atliko praktinę užduotị, o gautus rezultatus surašè PVP bloknote ir pateikè individualius darbus ịvertinti. Tada, panaudojus daugiakriterị pasiekimų tikrinimo sąrašą T1, buvo atliktas diagnostinis vertinimas ir pereita prie kitų mokymo etapų. Ta pačia tvarka etapais vyko tolesnis kariūnų mokymas.

Pradetas naudoti daugiakriteris vertinimo įrankis, mokant PVP, II kurso kariūnams buvo naujiena. Tradiciškai išmokimo vertinimas buvo paremtas paprastesne sistema ir priklausė labiau nuo vertintojo profesinès kompetencijos ir nuostatų. Dèl pasikeitusio vertinimo kariūnai pajuto nusivylimą, buvo juntamas tam tikras pasipriešinimas. Nors PVP mokymo etapų rezultatus buvo galima kur kas aiškiau ir objektyviau ịvertinti, tačiau, pasak II kurso kariūnų, išmokimo vertinimas tapo „,per 
griežtas “. Vis dèlto galima teigti, kad naudotas daugiakriterio vertinimo įrankis nebuvo kliūtis mokant PVP. Tikroji problema buvo susijusi su panaudoto įsakymo „Žaibas“ sudètingumu, kokybe ir kariūnų žinių stoka. Esant tokioms aplinkybèms, galèjo susidaryti ịspūdis, kad tai - dèl daugiakriterio vertinimo įrankio taikymo kilusi problema. Vis dèlto stebint, kad negerẻja kariūnų mokymo(si) pasiekimai (rezultatai) ir reikšmingai krinta jų motyvacija mokytis, buvo nuspręsta nuo T5 mokymo etapo reorganizuoti PVP dalyko mokymą ir vertinimą.

Pokyčiai nuo T5 mokymo etapo buvo sukurti spontaniškai, ieškant efektyvesnių sprendimų, kaip pagerinti kariūnų mokymo(si) rezultatus ir patirtis. Dèl to buvo pakeistas mokymo eiliškumas ir daugiakriterio vertinimo ịrankio taikymo ribos. Pirmiausia atsisakyta paskaitų skaitymo tam, kad būtų sudarytos sąlygos visą turimą laiką skirti praktiniam mokymui. Kiekvienas mokymo etapas pradètas išsiunčiant teorinę paskaitos medžiagą PDF formatu ị II kurso kariūnų elektroninio pašto děžutes. Tačiau esminiu pokyčiu galima laikyti tai, kad su teorine mokymo medžiaga buvo išsiųstas atitinkamo PVP mokymo etapo daugiakriteris pasiekimų tikrinimo sąrašas. Taigi, atskleisti daugiakriteriai pasiekimų tikrinimo sąrašai leido kariūnams sužinoti, kaip jie bus vertinami. Tai leido taikyti ne tik diagnostini vertinimą mokymo etapo pabaigoje, bet ir formuojamąji vertinimą paties mokymo metu per kariūnų savęs vertinimo praktiką. Nors PVP mokymo(si) ir rezultatų vertinimo procesų pokyčiai nebuvo planuoti, tačiau tai tapo objektyvia terpe inovacijos efektui įvertinti.

Daromos itakos mokymo(si) pasiekimu rezultatams ịvertinimas. Atliekant veiklos tyrimą pradejus taikyti daugiakriterio vertinimo įrankị buvo sudarytos palankios sąlygos per vienodą kiekybinį vertinimą gauti patikimus kariūnų pasiekimų rezultatus. Tačiau iki veiklos tyrimo modifikavimo II kurso kariūnų praktinių darbų ívertinimai buvo labai prasti: T1 $\sim 4,8(\sim 53,0$ balai), T2 $\sim 3,4(\sim 39,2$ balo), T3 3,6 ( 40,0 balu), T4 3,7 ( 41,3 balo). Svarbu atkreipti demesi i tai, kad neišlaikiusiuju PVP praktinių darbų įskaitos iš pirmo karto skaičius taip pat buvo didelis: T1 - 16 (43 proc.), T2 - 27 (73 proc.), T3 - 24 (65 proc.), T4 - 30 (81 proc.). Labai prastų ịvertinimų seka buvo aiškus indikatorius, kad būtina skubiai peržiūrèti mokymo, mokymosi ir vertinimo derinimo prieigas, o gal net ir paties mokymo turinị ir eigą. Galima teigti, kad taikant daugiakriterio vertinimo įrankius kariūnu profesionalumui buvo keliami aukšti reikalavimai. Reiklumas profesionalumui pats savaime nèra blogas dalykas, tačiau akivaizdu, kad taikant daugiakriterio vertinimo įrankị mokymo procese kartu reikia keisti ir patị mokymą. Tą atskleidžia ir kariūnų grịžtamieji atsiliepimai:

„Akivaizdžiai trūksta kažkokiu pagrindu, be kuriu labai sunku suprasti, kaip viskas vyksta net naudojantis PVP knyga, ypatingai žmogui, kuris nèra tarnavęs ar per daug susidūręs su kariuomenès veikla. Galbūt tai jau akademijos problema, kadangi visi ateiname su skirtingu žiniu bagažu, bet yra labai sunku ,žaliam “ žmogui ịvykdyti kai kuriuos jūsu reikalavimus, kai nepajègi isivaizduoti, kaip viskas vyktu realiai, kai bandai suvokti ir net nenumanai daugybès dalyku, juk civiliniam gyvenime to nera. "

Informantas $n$ r. 6 
Nors visada galima abejoti mokymo kokybe, vis dèlto išryškëja dilema - kaip ìvykdyti aukštus institucinius reikalavimus mokant PVP, išdėstytus mokymo programoje, kai II kurso kariūnų turimos žinios yra akivaizdžiai nepakankamos. Nepaisant iškilusios dilemos, buvo siekiama efektyvinti PVP pagrindų mokymą ji modifikuojant. Sprendžiant šią dilemą, pirmiausia buvo patobulintas treniravimo įrankis (PVP bloknotas), pereita nuo teorinių paskaitų prie tiesioginio mokymo(si) per praktiką (angl. learnig by doing) modelio. Vis dèlto esminis PVP mokymo efektyvumo ir kokybės proveržis ịvyko nusprendus daugiakriterị vertinimo įrankị naudoti atliekant ne tik diagnostinį, bet ir formuojamajị vertinimą. Tai sudare sąlygas pagerinti II kurso kariūnų PVP mokymosi rezultatus. Po veiklos tyrimo modifikacijos II kurso kariūnų praktinių darbų įvertinimai pagerèjo (žr. 2 pav.): T5 6,4 ( 67,7 balo), T6 5,9 ( 63,4 balo), T7 5,3 ( 57,3 balo). Būtina atkreipti dèmesị ir ị tai, kad neišlaikiusiųjų PVP praktinių darbų įskaitos iš pirmo karto skaičius reikšmingai sumažèjo: T5 - 0 (0 proc.), T6 - 9 (24 proc.), T7 - 12 (32 proc.).

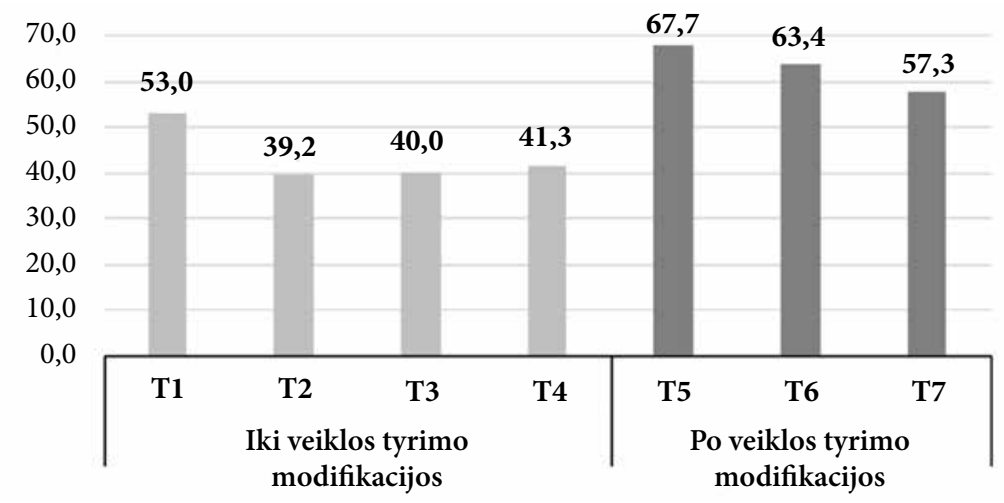

2 pav. II kurso kariūnų pasiekimų įvertinimų vidurkių (balais nuo 0 iki 100) lyginamasis grafikas

Po veiklos tyrimo modifikacijos II kurso kariūnų pasiekimų ịvertinimų vidurkis vidutiniškai pakilo nuo 3,9 (43,4 balo) iki 5,9 (62,8 balo), o neišlaikiusiuju PVP praktinių darbų įskaitos iš pirmo karto skaičius vidutiniškai sumažèjo nuo 24,3 (65,7 proc.) iki 7 (18,9 proc.). Pradejus taikyti daugiakriterio vertinimo ịrankị ir formuojamojo vertinimo metu II kurso kariūnų atliktų PVP praktinių darbų įvertinimai pagerèjo 51,3 proc. Reikšmingos ir gautų pažymių pasiskirstymo tendencijos, pateiktos gautų pažymių suminejje diagramoje (žr. 3 pav.). Žvelgiant ị diagramą galima matyti, kad veiklos tyrimo modifikacija ir priimti sprendimai sudare sąlygas kariūnų gautų pažymių dažnị reikšmingai pastumti ị dešinę. Galima buvo užfiksuoti ir labai aukštų pažymių gavimo faktų. 


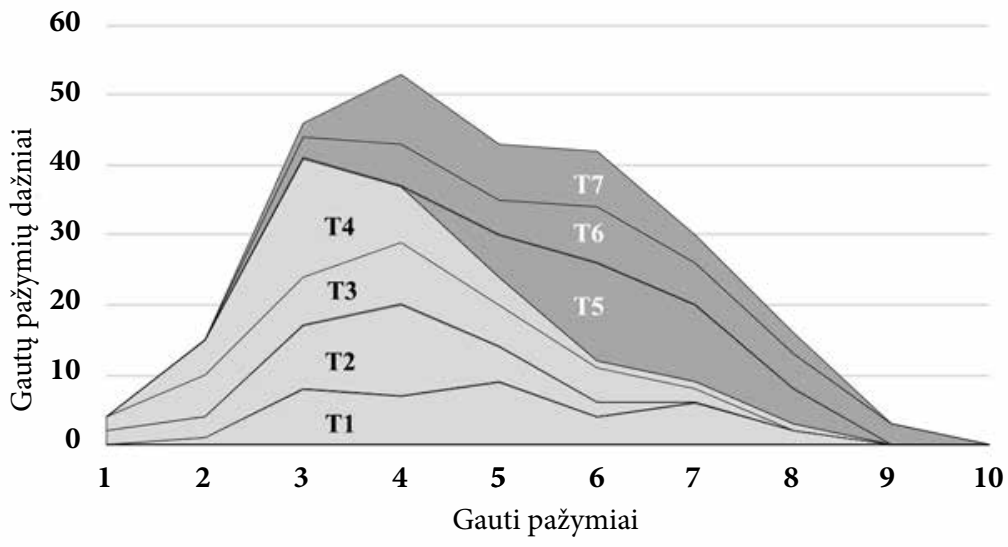

3 pav. II kurso kariūnų gautų pažymių kaitos diagrama

Remiantis atliktos statistinès analizès rezultatais, galima pagrịstai teigti, kad daugiakriterio vertinimo įrankio taikymas leido objektyviai išmatuoti II kurso pasiekimus, tačiau tuo pačiu metu kèlè aukštus reikalavimus jų profesionalumui. Tai teigiami efektai, vertinant kariūnų mokymo(si) procesą ir rezultatus, tačiau toks reiklumas padidino poreikị taikyti pažangesnius mokymo būdus. Tyrimas parodè, kad to paties daugiakriterio vertinimo irankio taikymas ir mokymo procese atliekant formuojamaji vertinimą leido reikšmingai pagerinti II kurso mokymosi rezultatus. Svarbu pažymèti, kad daugiakriteriuose pasiekimų tikrinimo sąrašuose kariūnui labai smulkiai nurodyta, ką konkrečiai reikia padaryti kiekviename PVP mokymo etape. Dèl šios priežasties kariūnas pats gali kokybiškai ịvertinti savo atliktus darbus, aiškiai suprasti, kaip šie jo darbai bus vertinami. Tai leidžia kariūnams nuosekliai patiems mokytis ir siekti geresnių PVP išmanymo rezultatų.

Daromos įtakos kariūnų nuostatoms, požiūriui i mokyma(si) ịvertinimas. Nors kariūnų pasiekimai svarbūs, ugdant ne ką mažiau reikšmingos ir kariūnų mokymo(si) patirtys. Tai nusako kariūnų nusistovejęs požiūris ị PVP mokymo(si) procesą. Neigiamos kariūnų nuostatos šiuo klausimu taip pat aiškiai rodè, kad reikalingos modifikacijos. Pastebėtas akivaizdus visuotinis kariūnų vidinės motyvacijos mokytis krytis. Ėmè reikštis ir kiti latentiniai padariniai, tokie kaip akivaizdaus nepasitenkinimo demonstravimas, tylus protestas ar užmigimo paskaitų metu atvejai. Be to, tikètina, kad dalis kariūnų dèl nesėkmių ir neigiamų patirčių mokydamiesi galejo patirti ir tam tikrą įtampą, stresą, nerimą ar baimę. Ivardytas problemas patvirtina ir grižtamuosiuose atsiliepimuose pateikti II kurso kariūnų ịvertinimai:

„Nesvarbu, kad atsirado keletas žilu plauku ties ausimis, stresas ir nepatogumai varo mus pirmyn. Kodèl tai sakau? Todèl, kad noriu apibūdinti savo jausmus, kol tęsiasi šis kursas. Isivaizduokite, nuostabiausia ir maloniausia diena šiais mokslo metais man jau buvo - ilgasis savaitgalis lapkričio pirmaja. Kodèl? Ogi todèl, kad žinojau, kad kita savaitę neteks nardyti PVP platybèse ir patirti jau mi- 
nèto streso. Viena gera diena savaitèje būna popietè ketvirtadieni po PVP, atslügsta visos savaités stresas, na o vèliau pradeda kauptis ir vèl. Nežinia, kada rinks, ar gausi bent jau teigiama, varo iš proto. “

Informantas $n$ r. 8

Iki veiklos tyrimo modifikacijos buvo galima pagrịstai abejoti, ar daugiakriteris vertinimo metodas apskritai yra tinkamas ugdymui vertinti. Vis dèlto po atliktos modifikacijos ir vẻliau gautų kariūnų grižtamųjų atsiliepimų galima daryti išvadą, kad problemų kilo ne dèl paties daugiakriterio vertinimo metodo ribotumo, o dèl netinkamų mokymo prieigų pasirinkimo. Tradicinès mokymo prieigos, tokios kaip paskaitos, nesuderinamos su daugiakriterio vertinimo metodu. Tačiau tokios prieigos kaip problemomis grịstas mokymasis (Savery, 2006), nesėkmèmis grịstas mokymasis (Tawfik et al., 2015), savivaldus mokymasis (Dudinskienė \& Žydžiūnaitė, 2014), atradimais grịstas mokymasis (Janssen et al., 2014) ir, galiausiai, žingsninis instrukcinis mokymasis (angl. Anchored Instruction) (Wang, 2019) yra tie sprendimai, kurie leidžia efektyviai naudoti daugiakriterio vertinimo metodą ugdymo srityje. Tokiam požiūriui pritaria ir II kurso kariūnai, kuriems žingsninis instrukcinis mokymasis, naudojant daugiakriterio pasiekimų tikrinimo sąrašus, buvo parankus ir priimtinas ne tik siekiant geriau perprasti PVP, bet ir igyti teigiamų patirčių:

„Labai malonu mokytis, ir viskas būna aiškiau, kai aiškinama , step by step “, tada galima įsivertint savo darba ir eiti klausti, kas blogai, nes žinai savo klaidas. "

Informantas nr. 3

„Manyčiau, tas pirminis nesusikalbejjimas ir vienas kito nesupratimas kilo dèl pirminio atmetimo, turiu omenyje, daug darbu, baimè, išgastis, ne viena valanda, praleista prie PVP, bet vis tiek rūkas, tada pagalvoji: „Ai, geriau plauksiu pasroviui, nei bandysiu kažka daryti. " Tačiau dabar manau, kad viska pataisème (santyki tarpusavyje), ir kuo toliau, tuo geriau seksis dirbant dèl bendro tikslo. “

Informantas nr. 4

„Atsižvelgus i mūsu norq mokytis ,, step by step“", mes pradedame vis daugiau ir aiškiau suprasti. Manau, tai yra tikrai geresnis büdas, nes jau dabar mes galime orientuotis ì mūsu baigiamaji PVP egzaminą. "

Informantas nr. 5

Remiantis kariūnų grịžtamuosiuose atsiliepimuose pateikta informacija, galima daryti išvadą, kad daugiakriterio vertinimo įrankio naudojimas mokant(is) PVP gali suteikti teigiamos patirties, jeigu pasirenkamos kitos mokymo prieigos. Septyni iš trylikos grịžtamajị atsiliepimą pateikusių kariūnų tiesiogiai įvardijo detalaus PVP pagrindų aiškinimo poreikị ir tokio mokymo(si) būdo teigiamą patirtį. Šiame tyrime buvo patvirtinta, kad žingsninis instrukcinis mokymasis leidžia efektyviai išnaudoti dugiakriterio vertinimo ịrankius mokant PVP, nes sudaro sąlygas kariūnams ịgyti 
daugiau žinių ir teigiamos patirties gilinantis į mokymo(si) procesą.

Tyrëjo refleksija apie daugiakriterio vertinimo ịrankio taikyma. Paprastai laikoma, kad ugdymo procese besimokančiujų pasiekimų rezultatai ir jų igytos patirtys yra svarbiausi aspektai. Tačiau neretai pamirštama, kad ugdymo procese svarbus vaidmuo tenka mokytojui, todèl svarbi jo patirtis ir ugdymo procesui keliami instituciniai reikalavimai. Mokytojui pasiekti pasitenkinimą savo darbu nèra lengva, kaip ir ugdymo institucijai nèra paprasta užtikrinti efektyvų ir kokybišką ugdymo procesą. Ir tai jau yra vadybos dalykai, nes tiek mokytojas, tiek ugdymo institucija dalyvauja ugdymo proceso valdyme. Ugdymo proceso valdytojai - mokytojai turi gebėti suderinti institucinius ugdymo ir besimokančiujų poreikius. Tai dažnai mokytojams kylanti dilema, su kuria tyrejui taip pat teko susidurti.

Ugdymo proceso, kuriame dalyvauja mokytojas ir besimokantieji, valdymas - subtilus menas ir mokslas, nes, kad šią sistemą ịvaldytų, mokytojui reikia labai gerai perprasti kontekstą. Tačiau svarbu pažymèti, kad mokymas yra išskirtinè mokytojo, o mokymasis - besimokančiojo atsakomybè. Tai dualistinis procesas, turintis veikti kaip darni visuma. Tyrimas atskleidè, kad daugiakriteris vertinimo metodas leidžia pasiekti kokybiškesnę mokymo ir mokymosi procesų dermę mokant(is) PVP. Pirmiausia daugiakriteris vertinimo įrankis leido aiškiai ir struktūrizuotai parodyti kariūnams, kokių žinių iš jų tikimasi po kiekvieno mokymo etapo. Be to, naudojant daugiakriterị vertinimo įrankị sumažèjo kariūnų netikrumas dèl ateities ir padidejo vidinè motyvacija veikti. Tokị efektą leido pasiekti kariūnų išankstinis žinojimas, kaip jie bus vertinami. Vis dèlto svarbu pažymèti, kad šie teigiami pokyčiai buvo fiksuojami tik atlikus veiklos tyrimo modifikaciją, kai daugiakriteriai pasiekimų tikrinimo sąrašai buvo pradèti naudoti ne tik kaip diagnostinio, bet ir kaip formuojamojo vertinimo ịrankiai. Remiantis tuo, galima pagrịstai teigti, kad daugiakriterio vertinimo įrankio viešumas yra būtinoji sèkmingo taikymo sąlyga. Vis dèlto tenka pripažinti, kad yra nelengva laužyti stereotipus ir iš anksto atskleisti besimokantiesiems, kaip jie bus vertinami. Nors ir nelengva, tačiau būtina, norint efektyviai taikyti daugiakriterio vertinimo įrankị mokymo(si) procese. Galiausiai tyrejjas pastebėjo ir kitą nelauktą efektą - padidejusị besimokančiuju įsitraukimą i mokymo(si) procesą. Tai taip pat leido pasiekti taikytas daugiakriterio vertinimo ịrankis. İsitraukimas pasireiškè tuo, kad kariūnai, žinodami, už ką konkrečiai buvo gautas neigiamas įvertinimas, savarankiškai ir grupèmis kreipèsi ị mokytoją, siekdami užpildyti žinių spragas. Tai taip pat didino mokytojo atskaitomybę besimokantiesiems, nes kiekvieną vertinimo aspektą buvo būtina įtikinamai argumentuoti. Dèl to galima teigti, kad taikant daugiakriterio vertinimo įrankị ir pačiam mokytojui kyla poreikis siekti aukštesnio profesionalumo.

Ugdymo proceso valdymas mokytojo ir ugdymo institucijos sistemoje yra tarpdisciplininè terpè, kur ,persidengia“ edukologijos ir vadybos interesai. Čia ugdymo institucija tipiškai per mokymo turini (curriculum) - tam tikrą mokomuju dalykų ir mokymo etapų seką - siekia nurodyti mokytojui tam tikrus mokymo siekinius, uždavinius ir tikslus, igyvendinamus per tam tikrą laiką ir tam tikroje erdvè- 
je. O mokytojas, tuo vadovaudamasis, turi šiuos mokymo siekinius, uždavinius ir tikslus įgyvendinti organizuodamas efektyvią edukologinę praktiką. Be konkrečiu reikalavimu mokymui, mokytojui reikia veikti, atsižvelgiant $\mathfrak{i}$ ịvairius apribojimus - laiko, išteklių, procedūrų, gebejjimų ir kt. Kitaip tariant, institucija išreiškia tam tikrą interesą, kuri mokytojas per edukologinę praktiką turi paversti tikrove. Tai dar viena dilema, kurią reikia spręsti mokytojui - kaip įgyvendinti institucinius interesus, esant tam tikrų apribojimų? Tyrejjui veiklos tyrimo metu reikèjo galvoti, kaip iggyvendinti aukštus PVP mokymo programos siekinius, jeigu II kurso kariūnai neturi jokių pradinių PVP taikymo ịgūdžiu, o jų karybos žinios yra labai ribotos ir netolygios. Šią dilemą padejjo spręsti taikytas daugiakriterio vertinimo įrankis. Kadangi daugiakriteris vertinimo įrankis yra aiškiai struktūruotas, jo pagrindu buvo galima kokybiškai restruktūruoti institucijos numatytą mokymo turinị ir mokymo etapų nuoseklumą. Tai leido aiškiau suvokti, kaip viename mokymo etape igytos žinios siejasi su žiniomis, kurios turès būti igytos kitame etape. Kitas svarbus daugiakriterio vertinimo įrankio panaudojimo aspektas buvo tai, kad jis ịgalino aiškiai apibrèžti reikiamą žinių gylį ir apimtị. Žinių gylio ir apimties apibrežtis igalino labai kryptingai veikti atsižvelgiant ị laiką, kuris buvo skirtas PVP mokyti(s). Svarbu pažymèti, kad daugiakriterio vertinimo ịrankis dèl savo kiekybinès prigimties nesunkiai gali būti pritaikomas ir naudojant ịvairias informacines technologijas. Atliekant veiklos tyrimą papildomai integruoti informacinių technologijų sprendimai leido pagerinti taikomo daugiakriterio vertinimo įrankio efektyvumą mokant(is) PVP. Tai taip pat pagerino ir ugdymo proceso vadybinę praktiką renkant, vertinant ir remiantis šiais vertinimais darant išvadas apie institucinių problemų sprendimų tobulinimo ugdymo srityje galimybes.

\section{Išvados}

1. Atliktas tyrimas atskleide, kad daugiakriteris vertinimo įrankis leidžia objektyviai išmatuoti kariūnų PVP dalyko mokymo(si) pasiekimų rezultatus. Be to, nustatyta, kad daugiakriteris vertinimo įrankis kelia aukštus reikalavimus profesionalumui. Kariūnai, norèję gauti teigiamą PVP tam tikros dalies žinių ịvertinimą, turejjo pademonstruoti geras vadybinio raštingumo žinias. Vis dèlto tikroji daugiakriterio vertinimo įrankio taikymo verte atsiskleidè tada, kai įrankis buvo pradètas taikyti atliekant ne tik diagnostini, bet ir formuojamaji vertinimą. Nustatyta, kad šiuo atveju II kurso kariūnų PVP mokymosi rezultatai pagerejo 51,3 proc., o neišlaikiusiujų PVP dalyko praktinių darbų ịskaitos iš pirmo karto skaičius sumažèjo 71,2 proc. Tai objektyvūs įrodymai, kad daugiakriterio vertinimo metodas padare teigiamą įtaką formuojant II kurso kariūnų mokomojo dalyko PVP žinias. Galima teigti, kad daugiakriteris vertinimo metodas yra perspektyvus teikiant ir ịsisavinant ir kitas būtinas vadybinio raštingumo žinias.

2. Nustatyta, kad netinkamai taikomas daugiakriteris vertinimo įrankis formavo neigiamą požiūrị i mokomojo dalyko PVP mokymą(si). Toks efektas pasi- 
reiškè, kai daugiakriteris vertinimo įrankis buvo taikomas tik atliekant diagnostinị vertinimą, kai daugiakriterio pasiekimų tikrinimo sąrašai nebuvo iš anksto žinomi II kurso kariūnams. Tačiau daugiakriterio vertinimo įrankio taikymas atliekant formuojamaji vertinimą paskatino teigiamus pokyčius. Užfiksuota, kad pasikeitė II kurso nuostatos dẻl PVP mokymo(si). 7 iš 13 grižtamajị atsiliepimą pateikusių II kurso kariūnų tiesiogiai ịvardijo ịgytas teigiamas mokymo(si) patirtis. Buvo stebimas II kurso kariūnų vidinès motyvacijos mokytis ir įsitraukimo į mokymo(si) procesą augimas. Vis dèlto svarbu pažymèti, kad, norint taikyti daugiakriterị vertinimo metodą ugdymo procese, būtina taip pat taikyti ir tinkamas mokymo prieigas. Nustatyta, kad žingsninis instrukcinis mokymas(is) - palanki prieiga, leidžianti efektyviai ir kokybiškai išnaudoti daugiakriterio vertinimo metodo teikiamas galimybes. Tokia kombinacija formavo II kurso kariūnų teigiamas nuostatas ir palankų požiūrị i PVP mokymo(si) procesą.

3. Atliekant tyrimą nustatyta, kad daugiakriteris vertinimo įrankis gali būti taikomas teikiant ir tobulinant vadybinio raštingumo žinias. Dèl to tikslinga plačiau taikyti daugiakriteri vertinimo metodą ugdyme. Taip pat nustatyta, kad daugiakriterio vertinimo metodo taikymas leidžia kokybiškai valdyti PVP mokymo(si) procesą tiek mokytojas-besimokantysis, tiek mokytojas-institucija sistemose. Vis dëlto galimybės taikyti daugiakriteri vertinimo metodą kompetencijoms ar charakterio savybėms ugdyti yra abejotinos. Kad šios prielaidos būtų patvirtintos arba atmestos, reikia atlikti papildomų tyrimų.

\section{Literatūra}

AAP-6 [LTU]. (2014). NATO terminu ir apibrěžčių žodynas [NATO Glossary of Terms and Definitions]. Versija lietuvių kalba. Patvirtinta Lietuvos karybos standartu LKS AAP-6(2014).

ADP 5-0. (2019). The Operations Process. In Army Doctrine Publication No. 5-0. Headquarters, Department of the Army, https://armypubs.army.mil/epubs/ DR_pubs/DR_a/pdf/web/ARN20305_ADP 5-0 FINAL WEB.pdf

ATP 3-21.10. (2018). Infantry Rifle Company. Headquarters, Department of the Army.

ATP 3-21.8. (2016). Infantry platoon and squad. Headquarters, Department of the Army.

BI-SC DIR 075-073. (2015). Education \& individual training directive. NATO Supreme Allied Commander, Europe B-7010 SHAPE.

BI-SC DIR 75-2. (2013). Education and training directive. NATO Supreme Allied Commander, Europe B-7010 SHAPE.

Bybee, R. W. (2003). The Teaching of Science: Content, Coherence, and Congruence. Journal of Science Education and Technology, 12(4), 343-358, https:// doi.org/10.1023/B:JOST.0000006280.59248.41

Cathcart, A., Greer, D., \& Neale, L. (2014). Learner-focused evaluation 
cycles: facilitating learning using feedforward, concurrent and feedback evaluation. Assessment \& Evaluation in Higher Education, 39(7), 790-802, https://doi.org/10. 1080/02602938.2013.870969

Česūnas, L. (2015). Padaliniu valdymo procedūros (V. Šerelis, M. Stackevičius, A. Kadys, D. Blažys, R. Gusev, D. Mineika, K. Stiga, D. Černiauskas, T. Klizas, T. Trepšas, \& P. Pidkovas (eds.)). Generolo Jonono Žemaičio Lietuvos karo akademija, https://kam.lt/download/57059/padalinių valdymo procedūrosl.pdf

Chang, T.-C., \& Wang, H. (2016). A Multi Criteria Group Decision-making Model for Teacher Evaluation in Higher Education Based on Cloud Model and Decision Tree. EURASIA Journal of Mathematics, Science \& Technology Education, 12(7), 1243-1262, https://doi.org/10.12973/eurasia.2016.1510a

Dikčius, V. (2011). Anketos sudarymo principai, http://www.evaf.vu.lt/dokumentai/katedros/Rinkodaros_katedra/Medziaga_studentams/Anketos_sudarymo_principai.pdf

Drisko, J. W. (2014). Competencies and Their Assessment. Journal of Social Work Education, 50(3), 414-426, https://doi.org/10.1080/10437797.2014.917927

Dudinskienė, L., \& Žydžiūnaitè, V. (2014). Savivaldaus mokymosi stiprybės ir silpnybès savarankiškai studijuojant socialinių mokslų magistrantūroje. Profesinés Studijos: Teorija Ir Praktika, 126-132, https://etalpykla.lituanistikadb.lt/object/ LT-LDB-0001:J.04 2014 1516970347847/J.04 2014 1516970347847.pdf

FM 3-21.10. (2006). The Infantry Rifle Company. In Army Field Manual No. 3-21.10. Headquarters, Department of the Army.

FM 3-21.8. (2007). The Infantry Rifle Platoon and Squad. In Army Field Manual No. 3-21.8. Headquarters, Department of the Army.

Fokienè, A., \& Sajienè, L. (2009). Portfolio metodas vertinant neformaliojo ir savaiminio mokymosi pasiekimus. Aukštojo mokslo kokybè, 6, 141-159.

Gatautis, R., Gudauskas, R., Gurskienè, O., Jovaiša, T. R., Laužackas, R., Stravinskienè, J., Tūtlys, V., \& Valiukėnas, V. (2008). Aiškinamasis kvalifikaciju sistemos terminu žodynas [Explanatory dictionary ofqualification system terms].

Generolo Jono Žemaičio Lietuvos karo akademijos strategija 2018-2024 metams, (2019).

Ginevičius, R., \& Podvezko, V. (2008). Daugiakriterinio vertinimo taikymo galimybės kiekybiniam socialinių reiškinių vertinimui [A feasibility study of multicriteria methods' application to quantitative evaluation of social phenomena]. Verslas: Teorija ir praktika [Business: Theory and Practice], 9(2), 81-87, https:// doi.org/10.3846/1648-0627.2008.9.81

Gudžinskienè, V. (2011). Konstruktyvizmo ištakos Lietuvoje ugdant socialinius ịgūdžius. Pedagogika, 103, 38-44.

Hawe, E., \& Dixon, H. (2017). Assessment for learning: a catalyst for student self-regulation. Assessment \& Evaluation in Higher Education, 42(8), 1181-1192, https://doi.org/10.1080/02602938.2016.1236360

Janssen, F. J. J. M., Westbroek, H. B., \& van Driel, J. H. (2014). How to make 
guided discovery learning practical for student teachers. Instructional Science, 42(1), 67-90, https://doi.org/10.1007/s11251-013-9296-z

Jovaiša, L. (2007). Enciklopedinis edukologijos žodynas. Gimtasis žodis.

Katinienè, A. (2018). Organizacijos darbuotojų žinių sinergijos vertinimas [Evaluation of organisation employee knowledge synergy] [Technika]. In daktaro disertacija [doctoral dissertation], https://doi.org/10.20334/2018-017-m

Ketkar, M., \& Vaidya, O. S. (2014). Evaluating and Ranking Candidates for MBA Program: Mahalanobis Taguchi System Approach. Procedia Economics and Finance, 11, 654-664, https://doi.org/10.1016/S2212-5671(14)00231-7

Li, J., Li, Z., Liu, S.-F., \& Cheng, M. (2019). Applying a fuzzy, multi-criteria decision-making method to the performance evaluation scores of industrial design courses. Interactive Learning Environments, 1-15, https://doi.org/10.1080/104948 20.2019.1636080

Lin, T.-C., Ho, H.-P., \& Chang, C.-T. (2014). Evaluation Model for Applying an E-Learning System in a Course: An Analytic Hierarchy Process-Multi-Choice Goal Programming Approach. Journal of Educational Computing Research, 50(1), 135157, https://journals-sagepub-com.ezproxy.vdu.lt:2443/doi/pdf/10.2190/EC.50.1.g

Manfra, M. M. (2019). Action Research and Systematic, Intentional Change in Teaching Practice. Review of Research in Education, 43(1), 163-196. https://doi. org/10.3102/0091732X18821132

Ramonienè, M., Brazauskienè, J., Burneikaitè, N., Daugmaudytè, J., Kontutytė, E., \& Pribušauskaitė, J. (2012). Lingvodidaktikos terminu žodynas, http://www.lsk.flf.vu.lt/file/Lingvodidaktikos_terminu_zodynas_2012_2.pdf

Sarraf, A. Z., Mohaghar, A., \& Bazargani, H. (2013). Developing TOPSIS method using statistical normalization for selecting knowledge management strategies. Journal of Industrial Engineering and Management, 6(4), 860-875, https://doi.org/10.3926/jiem.573

Savery, J. R. (2006). Overview of Problem-based Learning: Definitions and Distinctions. The Interdisciplinary Journal of Problem-Based Learning, 1(1), 9-20, https://doi.org/10.7771/1541-5015.1002

Scott, S., \& Webber, C. F. (2008). Evidence-based leadership development: the 4L framework. Journal of Educational Administration, 46(5), 762-776, https:// doi.org/10.1108/09578230810908343

Shee, D. Y., \& Wang, Y.-S. (2008). Multi-criteria evaluation of the webbased e-learning system: A methodology based on learner satisfaction and its applications. Computers \& Education, 50(3), 894-905, https://doi.org/10.1016/J. COMPEDU.2006.09.005

Simanavičienè, R., \& Ustinovičius, L. (2011). Daugiatikslių sprendimo prièmimo metodų jautrumo analizè taikant Monte Karlo modeliavimą. Informacijos mokslai, 56(0), 182-190, https://doi.org/10.15388/Im.2011.0.3138

Stonkus, S. (2002). Sporto terminu žodynas. Lietuvos kūno kultūros akademija. 
Tawfik, A. A., Rong, H., \& Choi, I. (2015). Failing to learn: towards a unified design approach for failure-based learning. Educational Technology Research and Development, 63(6), 975-994, https://doi.org/10.1007/s11423-015-9399-0

Tripp, D. (2005). Action research: a methodological introduction. Educação e Pesquisa, 31(3).

Tsai, C. (2014). The Confucian View of the Relationship between Knowledge and Action and Its Relevance to Action Research. Educational Philosophy and Theory, 46(13), 1474-1486, https://doi.org/10.1080/00131857.2014.966301

Tūtlys, V., Kaminskienè, L., \& Pileičikas, G. (2015). Kompetenciju vertinimo užduočiu sudarymo metodika, https://www.kpmpc.lt/kpmpc/wp-content/uploads/ akreditacija/Kompetenciju_vertinimo_uzduociu_sudarymo_metodika.pdf

Valuckienè, J. (2009). Mokymosi paradigma grịstos studijos kaip atsakas i besikeičiančios visuomenès lūkesčius universitetinèms studijoms. Ekonomika ir vadyba: Aktualijos ir perspektyvos, 2(15), 311-317.

Wang, Y.-H. (2019). Exploring the effectiveness of adopting anchor-based game learning materials to support flipped classroom activities for senior high school students. Interactive Learning Environments, 1-20, https://doi.org/10.1080/ 10494820.2019.1579238

World Economic Forum. (2015). New Vision for Education: Unlocking the Potential of Technology, http://www3.weforum.org/docs/WEFUSA_New VisionforEducation_Report2015.pdf

Zare, M., Pahl, C., Rahnama, H., Nilashi, M., Mardani, A., Ibrahim, O., \& Ahmadi, H. (2016). Multi-criteria decision making approach in E-learning: A systematic review and classification. Applied Soft Computing, 45, 108-128, https:// doi.org/10.1016/J.ASOC.2016.04.020 


\title{
TESTING A MULTI-CRITERIA EVALUATION TOOL FOR TROOP-LEADING PROCEDURES TEACHING
}

\author{
Gintautas Razma
}

General Jonas Žemaitis Military Academy of Lithuania

\begin{abstract}
Summary
Troop-leading Procedures are the most important discipline in cadets' military education. The aim of the subject of Troop-leading Procedures is to teach the cadet to apply a systematic planning algorithm to solve typical and recurring problems in military activity. This is one of the most important components of a future officer's military management literacy. While this is an important subject matter, however, there is a lack of reliable military teaching approaches. The article investigates whether the multi-criteria evaluation method can be applied in the teaching and evaluation of the subject of Troop-leading Procedures. Action research has practically tested a multi-criteria evaluation tool in teaching. The study revealed that the multi-criteria evaluation method can be successfully applied in the teaching of the subject of Troop-leading Procedures and in the evaluation of the teaching process. It has been established that this innovation creates conditions for improving the results of achievement assessments, provides positive experiences, forms positive attitudes towards teaching and learning, also helps the teacher to act more effectively during teaching.
\end{abstract}

Keywords: military education, Troop-leading Procedures, multicriteria evaluation, evaluation of the teaching process. 